IRA-International Journal of Management \& Social Sciences

ISSN 2455-2267; Vol.05, Issue 02 (2016)

Pg. no. 203-214

Institute of Research Advances

http://research-advances.org/index.php/RAJMSS

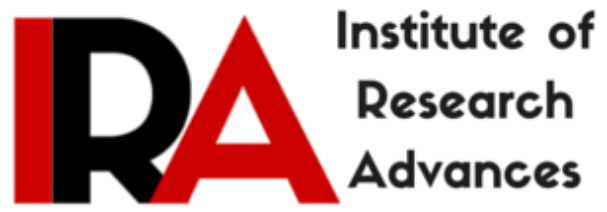

\title{
Measures of Organizational Effectiveness: Public Sector Performance
}

\author{
${ }^{1}$ A. Rahmawati \\ PhD Scholar, Post Graduate School of Economics, \\ University of Hasanuddin, Makassar, Indonesia.
}

Siti Haerani ${ }^{2}$, Muh. Idrus Taba ${ }^{3}$, Nurjannah Hamid ${ }^{4}$

${ }^{\mathbf{2 , 3 , 4}}$ School of Economics University of Hasanuddin, Makassar, Indonesia.

Type of Review: Peer Reviewed.

DOI: http://dx.doi.org/10.21013/jmss.v5.n2.p1

\section{How to cite this paper:}

Rahmawati, A., Haerani, S., Taba, M., \& Hamid, N. (2016). Measures of Organizational Effectiveness: Public Sector Performance. IRA-International Journal of Management \& Social Sciences (ISSN 2455-2267), 5(2), 203-214. doi:http://dx.doi.org/10.21013/jmss.v5.n2.p1

(C) Institute of Research Advances

\section{(cc) BY-NC}

This work is licensed under a Creative Commons Attribution-Non Commercial 4.0 International License subject to proper citation to the publication source of the work.

Disclaimer: The scholarly papers as reviewed and published by the Institute of Research Advances (IRA) are the views and opinions of their respective authors and are not the views or opinions of the IRA. The IRA disclaims of any harm or loss caused due to the published content to any party. 


\section{ABSTRACT}

This study aims to investigate and analyze the influence of leadership, competence, OCB behavior of an employee's performance against organizational effectiveness at 209 employees working at the regional work units (SKPD) Provincial Government of South Sulawesi. The hypothesis was tested using Structural Equation Model (Analysis of Moment Structures, AMOS version 18). The results of the study provide evidence that the leadership and competencies that can improve $O C B$ employee for the better. Good leadership and high competence and OCB employee can increase employee performance management to a higher direction. Leadership and competence cannot increase the effectiveness of the organization towards high, while the OCB employee and management performance that can increase the organizational effectiveness.

Keywords: leadership, competence, OCB, performance management, organizational effectiveness

\section{Introduction}

The One objectives of the organization is the increased performance of the individual, that the improved performance of the individual, the increase organizational effectiveness can be achieved. Effectiveness is the relationship between the results with the goal, the greater the contribution that in doing achieving the goal, the more effective the organization (Mahmudi, 2005). To ensure the ultimate success of an organization must be able to meet the three requirements of important behaviors, namely: (1). Organizations must be able to foster and maintain a stable workforce consisting of highly skilled personnel; (2). Organizations must be able to enjoy a reliable accomplishment role of the personnel, in this case any personnel not only required to be willing to work, but must also carry out specific tasks that are the responsibility of the main; (3). The personnel should strive to behave spontaneously and innovative, thus any personnel not only behave passively (Katz \& Kahn, 1978).

There are three main perspectives in analyzing the effectiveness of the organization, namely; (1). Perspective optimization purposes, namely effectiveness assessed according to a measure of how much an organization managed to achieve a worthy goal achieved. Focusing on a worthy goal achieved optimally, allowing clearly recognizable assortment of often conflicting objectives, as well as to note some of the obstacles in order to achieve objectives; (2). System perspective, the effectiveness of the organization in light of the integration of a variety of factors related to follow a pattern, input, conversion, output and feedback, and to include the environment as an external factor. In this perspective the goal is not treated as an end state is static, but as something that can be changed in the course of time. Achieving the objectives of certain short-term may be treated as a new input for further determination; (3). The perspective of human behavior, namely the concept of organizational effectiveness emphasis on people behavior in the organization that affects the success of the organization's long-term period. Do integration between the behavior of individuals and groups as the unit of analysis, assuming that the only way to achieve the goal is through the behavior of people in the organization (Steers, 1985:5).

The occurrence of changes in the organization also has impact in changes in the duties and obligations of employees. Employees are expected to become more creative to find new ways to improve the effectiveness and efficiency of work in the organization. When organizations reduce the number of employees, the organization will be more dependent on the employees who remained to do things beyond what was assigned to them (Yudhaningsih, 2011). The creation of 
organizational effectiveness, one of which resulted performance of individual (employee performance), poor employee performance in public sector, demonstrated by the quality of the waiter who was uncomfortable given to public servants, then the erroneous calculation of the various obligations that must be paid community. Such conditions would create an atmosphere of discomfort and create a bad image within the community towards public institutions, thus making the service organization is not effective (Titisari, 2012).

The effectiveness of the organization that the maximum can be created through the willingness of employees to work out the role (extra role performance), extra-role is crucial for the effectiveness of the organization, in order to improve the performance of the organization that will ultimately have an impact on the viability of the organization, especially in a business environment that is volatile at this time (Konovsky \& Pugh, 1994). Extra-role is a behavior that is very much appreciated when performed by employees, though not formally showed because it will increase the effectiveness and viability of the organization. OCB is a term used to identify the employee's behavior so that he can be called a good member (Sloat, 1999). Competence is something that is important for a job in an organization in which the shape and the level of employee behavior are different. Therefore competence showing the characteristics of knowledge and skills possessed or needed by any individual who is able to compete in performing their duties and responsibilities effectively and improve the professional quality standards of their work (Rivai et al., 2008: 97). The level of success in the work will be determined by the ability of a competent good position as an employee or position as a leader (Palan, 2007: 17). The success of the group or organization depends on the effectiveness of a leader. Leadership is a process of moving people in an organization because it has the power, authority and ability to work in an atmosphere of high morality with passion can complete their work according to the results expected (Semin \& Fiedler, 1996). The statement explained that leadership is an antecedent work motivation which in turn affects the increase organizational effectiveness.

\section{Literature review and Research hypothesis}

Leadership

Success of groups, organizations and even the whole country depends on the effectiveness of a leader (Semin \& Fiedler, 1996). Leadership is behavior that gives purpose, meaning and guidance for the collectivity to articulate a collective vision as awareness of the values of the organization (House, 1995; 413). The organization's leadership is the ability to influence others to do the task for a certain period of time by using the methods of motivation rather than power or authority (Kotter, 1996). The theory of leadership at government agencies today still focuses on transformational leadership and transactional leadership. According to this theory, there are two basic levels of real influence in the interaction between leaders and followers. One of the effects comes from an understanding that leaders create interaction costs by benefit their constituents.

Conceptually, transformational leadership is defined Bass et al. (2003) as the ability of a leader to change the work environment, work motivation and work patterns, and work values are perceived subordinates so that they are better able to optimize the performance to achieve organizational goals. Transformational process occurs in association leadership when followers of leaders to build awareness of the importance of work values expand and increase the need goes beyond personal interests and to encourage changes in the direction of common interests, including the interests of the organization. The process can be seen through a number of transformational leadership behaviors such as: attributed charisma; idealized influence; inspirational motivation; intellectual stimulation and individualized consideration (Bass et al., 2003). Previous studies analyzing the variables of leadership based on the perspective of subordinates, the findings of these studies indicate that transformational leadership has a positive effect stronger than the 
transactional leadership, the attitude of the employees on the job, the work environment, and ultimately influence their performance in work (Burns, 1978; Bass, 1985).

Transactional leadership is a leadership style that emphasizes core transaction between leaders and followers. Transactional leadership allows leaders motivate and influence followers by way of exchanging reward with a certain performance. Arguments against the reward encourages Bass et al. (2003) to define the transactional leadership as a form of relationship that exchange positions or a specific task if the subordinate is able to finish well the task given. Political leaders motivate followers by exchanging rewards for services rendered (Burns, 1978). Transactional leadership style is divided into two dimensions include; contingent reward and management by exception (Bass et al., 2003). Leadership style can contribute to the development of more powerful in perception means organizations and individuals. This causes increased OCB (Zang et al., 2010). Transactional leadership and transformational leadership can be influence OCB, either individually or together (Walumba et al., 2008). Leadership style on employee performance has a positive effect on employee performance which includes the dimensions of the work and effectiveness of the organization (Tintin, 2015). Leadership style has a significant effect on OCB (Ahmad et al., 2010). Competence significantly effect on performance through OCB (Sudarma, 2012)

Thus, we hypothesize that:

$\mathrm{H}_{1}$ : Good leadership can be improve OCB employees

$\mathrm{H}_{2}$ : Good leadership can be improve performance management

\section{Competence}

Competence is an ability to execute or perform a job or task that is based on skills and knowledge and supported by the nature of the work required by the job (Wibowo, 2007: 110). Competence is defined as an underlying characteristic's of an individual on which is causally related to criterionreferenced effective and or superior performance in a job situation (Mitrani et al., 1992; Spencer $\&$ Spencer, 2008).

Competence can be described; (1) threshold competencies include basic knowledge, skills, traits, motives, self-image and social role and are essential for performing a job; and (2) differentiating competencies are characteristics that have superior performers but average performers lack (Becker, 2004). Competence can be distinguished based on their characteristics (Wibowo, 2009: 111), namely; (1) motive, something that consistently thinks or wants the person who caused the action; (2) the nature, physical characteristics and response is consistent with the situation or information; (3) the concept itself, is an attitude, values, or the image of oneself; (4) confidence is a belief that they can be effective in every situation; (5) knowledge, is the information people have in their specific field. Knowledge is a complex competence; and (6) the skills, the ability to do certain physical or mental tasks. Studies conducted by previous researchers provide evidence the competence influence on organizational effectiveness, better utilization of human resources will be achieved so that the effectiveness of the organization's goals can be achieved (Apriani, 2011). Performance management cycle, measure the quality of human resources plays a central role which acts as a parameter the achievement of the targets that are expected to achieve organizational goals effectively (Chang, R., 2011).

We hypothesize that:

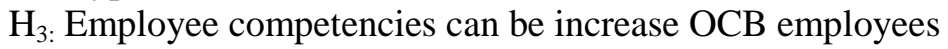

$\mathrm{H}_{4}$ : Employee competencies can be increase performance management

Performance Management

Performance Management is a process of continuous communication and carried out by a partnership between employees with the immediate supervisor. This process includes building a 
clear expectation and understanding of the work performed. This means that performance management has a number of parts which all must be included in every activity that adds value to the organization (Bacal, 2001: 111). Discourse between performance management with performance evaluation that is still synonymous with job evaluation. Provide an assessment or evaluation of the performance only is a part of the performance management system, while the performance evaluation is a process to assess and evaluate the performance of individuals. This process is the answer to a simple question of how well the performance of an employee during a certain time period (Bacal, 2001: 112). Another view explaining the performance management as a working process of the collection of people to achieve the goals that have been set, in which process this work takes place in a sustainable and continuous (Baird, 1986). Performance management is the process of consolidating a goal setting, assessment, and development of performance into a single system together, which aims to ensure the performance of the employees support the company's strategic goals (Dessler, 2003: 322).

The purpose of performance management (Williams, 1998; Armstrong \& Baron, 2005), that is; (1) regulating the performance of the organization with a more organized; (2) determine how effectively and efficiently an organization's performance; (3) assist the formation of organizational decisions relating to the performance of the organization, the performance of each part of the organization, and individual performance; (4) improve the overall ability of the organization to continual improvement; and (5) encourage employees to work according to the procedure, with the spirit, and productive, so the work optimally. In the epistemology of the performance comes from the performance or mean performance, performance or achievements of the work is the desired outcome of the perpetrator (Gibson et al., 1996).

Performance is the result of the quality and quantity of work that can be achieved by a person in performing its duties in accordance with the responsibilities given job (Mangkunegara 2005: 9). Performance measurement in this study is the measurement of individual performance with a selfassessment. Self-assessment is an assessment that is done in the hope that employees can get to know his strengths and weaknesses so as to identify the aspects of work behaviors that need to be repaired in the future. One of the good in this method is that it can prevent behavior that always justify themselves (defensive behavior). This method is called to approach the future because the employee will improve us in order to perform the tasks of the future better. Some of the reasons for the use of self-assessment (Rivai, 2008: 67), namely; (1) individuals can participate in the assessment process; (2) increase the motivation of individuals assessed so as to follow a healthy competition among employees and in addition can reduce rejection when assessed; (3) the individual can fix yourself; (4) the individual can determine the goals will come independently; (5) train the individual to decide and plan their own career in the future. Measurements used in analyzing the performance of employees on the study done by developing individual performance measurement (Mangkunegara, 2005; 67; Gomes, 2001), namely; (1) the quantity; (2) quality of work; and (3) punctuality. Performance management is a strategic approach and integrated to deliver sustained success on organizational effectiveness by improving the performance of employees who work in them and by developing the capabilities of the team and individual contributions (Armstrong \& Baron, 2005).

Thus, we hypothesize that:

$\mathrm{H}_{5}$ : Performance management can be improve organizational effectiveness

Organizational Citizenship Behaviors (OCB)

OCB has been studied since the late 1970s. Over the past three decades, the interest of researchers to this behavior has increased substantially. Based on historical roots, OCB is a form of cooperative behavior such as: (1) willing to join and stay, the willingness to join and remain in a system (organization), (2) dependable role performance which is a behavior that can be relied 
upon to be able to meet and even exceed the minimum criteria either qualitatively or quantitatively, (3) Innovative and spontaneous behavior as a form of behavior outside the role required by a job for people who question can finish the job (Katz \& Kahn, 1978). OCB as individual behavior is discretionary, not directly or explicitly recognized by the system of formal recognition, and that in aggregate increase the effective functioning of the organization (Organ, 1988).

OCB help change the atmosphere of the organization formally became a little relaxed and full cooperation. It is expected that with an atmosphere like that, the tension among employees can be reduced and therefore the atmosphere that supports the expected productivity of employees increases, so will achieve effectiveness with efficiency. OCB can smooth and launched a social life in an organization (Smith et al., 1983). OCB is free to determine the individual's behavior, which is not directly or explicitly recognized by the formal reward system, and together will encourage the organization function more effectively (Organ, 1990). OCB measurements, covering several dimensions (Organ, 1988); (1) altruism; (2) civic virtue; (3) conscientiousness; (4) courtesy; and (5) sportsmanship. Studies conducted by previous researchers provide evidence that OCB can bring a positive impact on the performance of the individual so that the effectiveness of the organization to be better (Hofstede, 2001). OCB have significant effect on organizational effectiveness (Begum, 2005; Foote \& Tang, 2008). OCB supports organizational performance by launching a social activity that can improve organizational effectiveness (Smith et al., 1983). There is a significant correlation between high group results in terms of quantity while the quality of the work cannot be found to do (Podsakoff et al., 1997). Other findings, that OCB has a positive impact on individual performance and individual performance subsequently have a positive impact on organizational effectiveness (Pattanaik \& Biswas, 2005).

We hypothesize that:

$\mathrm{H}_{6:} \quad$ OCB employees can be improve performance management

$\mathrm{H}_{7}$ : OCB employees can be improve organizational effectiveness

Organizational effectiveness

The greater achievement of organizational goals in the greater goal effectiveness (Gunadi, 2007), Effectiveness emphasized in effect, result, and less about the sacrifices that need to be given to obtain these results. Other views, said the effectiveness of a relationship between the output with the goal, the greater the contribution output to the achievement of the goal, the more effective the organization, program, or activity (Mahmudi, 2005). The statement has similarities with other views, that the effectiveness, on the other hand, is the ability to choose appropriate objectives. An affective manager is one who selects the right things to get done (Moenir, 2006).

According to Sudarwan (2004), measures of effectiveness include; (1) the number of results issued; (2) the level of satisfaction derived; (3) the creation of conditions conducive to do with the world of work; and (4) the intensity to be achieved. Steers (1985) states the measurement of organizational effectiveness can be done with, namely; (1) characteristics of the Organization; (2) the characteristics of the environment; (3) characteristics of workers; and (4) the characteristics of the management. The findings of previous researchers provide evidence that the leadership has a significant influence on the effectiveness of the organization. The belief in the leadership is an important part in improving organizational effectiveness (Dirks \& Ferrin, 2002). To be a good leader requires experience and understanding of situational, so that a good leader is able to provide feedback to the productivity, effectiveness, satisfaction and motivation which can then improve organizational effectiveness.

Thus, we hypothesize that:

$\mathrm{H}_{8:} \quad$ Good leadership can be improve organizational effectiveness

$\mathrm{H}_{9} \quad$ Employee competencies can be improve organizational effectiveness 


\section{Method}

This research uses explanatory research, using observations in cross-section at the Regional Work Units (SKPD) South Sulawesi Provincial Government to use 209 employees as the unit of analysis.

\section{Results}

This study describes the characteristics of the respondent is the identity of the respondents including gender, educational level and job tenure.

\section{Table 1.Participants}

\begin{tabular}{|l|l|c|c|}
\hline \multicolumn{2}{|c|}{ Participants' Profile } & n & \% \\
\hline \multirow{3}{*}{ Gender } & Male & 145 & 69,4 \\
\cline { 2 - 4 } & Female & 64 & 30,6 \\
\cline { 2 - 4 } & & & \\
\hline \multirow{4}{*}{ Job tenure (years) } & $<15$ & 3 & 1,5 \\
\cline { 2 - 4 } & $15-30$ & 184 & 88,0 \\
\cline { 2 - 4 } & $>30$ & 22 & 10,5 \\
\cline { 2 - 4 } & & & 14,8 \\
\hline \multirow{3}{*}{ Educational level } & Undergraduate & 31 & 81,3 \\
\cline { 2 - 4 } & Master degree & 170 & 3,8 \\
\cline { 2 - 4 } & Doctoral degree & 209 & $100 \%$ \\
\hline Total & & & \\
\hline
\end{tabular}

There are $69.4 \%$ of respondents are male and $30.6 \%$ female, so it looks male respondents who dominate. Master degree of visible $81.3 \%$, doctoral degree $3.8 \%$ and $14.8 \%$ is an Undergraduate. The test results show that the models of the eight criteria for 'goodness of fit' the model of structural index were constructed to estimate the parameters in accordance with the data of observation. Overall criteria had already qualified minimum threshold (cut-off point) required, such as the value of Chi-square with a cut-off value $=292,191>235,077$, Probability $=0.000 \geq$ $0.05 \mathrm{RMSEA}=0.047 \leq 0,08, \mathrm{CMIN} / \mathrm{DF}=1,454 \leq 2: 00, \mathrm{GFI}=0.898 \geq 0.90, \mathrm{AGFI}=0.859 \geq$ $0.90, \mathrm{CFI}=0.947 \geq 0.95, \mathrm{TLI}=0,933 \geq 0.95$ (Hair et al., 2006)

$\mathrm{H}_{1}$ : Good leadership can be improve OCB employees

Leadership has a positive and significant effect on OCB with the p-value of $0.000>0.05$ and a coefficient standardized amounted to 0.372 , the better the leader in carrying out its duties and responsibilities, the more it will improve employees OCB in the right direction (supported $\mathrm{H}_{1}$ ). Good leadership will encourage OCB getting better. These findings support the results of research Shahzad et al. (2010), that the leadership styles have a significant effect on OCB. Intellectual Stimulation represents a leadership style according to respondents; it does give an idea that the leader able to foster new ideas, providing creative solutions to the problems faced subordinates, and motivating subordinates to look for new approaches in carrying out organizational tasks. The findings of this study support the notion that aspects of intellectual stimulation positively correlated with extra effort (Seltzer \& Bass, 1990).

The results of confirmatory factor analysis testing showing main indicators that make up the leadership variable are Intellectual Stimulation. OCB is best shown through civic virtue. These facts provide evidence that good leadership will encourage employees OCB in the right direction, this is evidenced by the willingness of leadership provides a creative solution to the problems faced by subordinates, and motivating subordinates to seek approaches new carry out organizational tasks it is encouraging to follow the development of the organization, follow the 
rules, helping colleagues for the progress of the organization, it is certainly younger to do as leaders already have a working life relatively long time.

$\mathrm{H}_{2}$ : Good leadership can be improve performance management

Leadership has a positive and significant effect on performance management with a p-value of $0.000>0.05$, the better the leader in carrying out its duties and responsibilities, management performance will be high (supported $\mathrm{H}_{2}$ ). Studies History proves that leadership style has a positive impact on employee performance is reflected through the work and effectiveness of the organization (Tintin, 2015). Responder show leadership able to foster new ideas, providing creative solutions to the problems faced by subordinates, and provide motivation to subordinates to seek approaches new in carrying out the tasks of the organization, this can be done because of the leadership of a good understanding of organizational goals and objectives of the work carried out in accordance with the organization's strategic plan, have a clear understanding of the goals and objectives of the institution where the work, with such an understanding leader can supervise the performance of subordinates, it is certainly supported by the experience of leaders who've been in the field in a long time.

The results of confirmatory factor showed that the leadership is characterized by job satisfaction and understanding of organizational objectives and targets of the work. SKPD leaders were able to innovate to complete the work in the institution he leads, are satisfied with their work, the support of subordinates so that they can finish the job with a very good set. This finding supports, that the leadership as a process of influencing a group of people that want to work in earnest to achieve the goals of the group (Rivai, 2008).

$\mathrm{H}_{3:}$ Employee competencies can be increase the OCB employees

Competence has a positive and significant effect on OCB with a p-value of $0.000>0.05$ and a coefficient standardized of 0.607 , that the higher employees competences, the better OCB employees (supported $\mathrm{H}_{3}$ ). These findings support the results of research Sudarma (2011) the competence can increase OCB into a good direction. Indicator and important confirmatory factor analysis showed that competencies required of employees at the start of its ability to influence colleagues, this capability can run well when employees can give a good example, which must be accompanied by a good knowledge; capabilities will help in completing the job quickly.

$\mathrm{H}_{4}$ : Employee competencies can be increase performance management

Competence has a positive and significant effect on performance management with a p-value of $0.003>0.05$ with a coefficient standardized of 0.312 , this coefficient indicates that the better the competences of the employees, the performance management will get better (supported $\mathrm{H}_{4}$ ). These findings support the results Dali \& Mas'ud (2014) that the professionalism of auditors can enhance job satisfaction and performance. The results of confirmatory factor analysis indicate that the social role is an indicator of the dominant form of variable competence, ability to be a good role model and mediates organizational changes give satisfaction to yourself and to the subordinate, then the ability to discuss with subordinates will encourage a good understanding of organizational goals and objectives of work done.

$\mathrm{H}_{5}$ : Performance management can be improve organizational effectiveness

Performance management has significant effect on organizational effectiveness with p-value of $0.045>0.05$ and a coefficient standardized by 0.181 , this coefficient indicates that the higher levels of performance management, the higher levels of organizational effectiveness (supported $\mathrm{H}_{5}$ ). This study supports the concept of performance management presented Armstrong \& Baron (2005), that performance management is a strategic approach and integrated to deliver sustained success on organizational effectiveness by improving the performance of employees who work in 
them and by developing the capabilities of the team and individual contributions. The results of confirmatory factor analysis showed that performance management is reflected by the ability to carry out a very important work to be done according to plan strategies, these capabilities lead to contentment in the leadership, it can be created if the characteristics of the organization is already well where everyone in the organization was given the task and responsibility according to their ability.

$\mathrm{H}_{6:} \quad$ OCB employees can be improve performance management

OCB has a positive and significant effect on performance management with a p-value of $0.000>$ 0.05 and a coefficient standardized by 0.458 , this coefficient indicates that the better OCB will be the high management performance (supported $\mathrm{H}_{6}$ ). These findings support the results of research Schleicher et al. (2004) found that there is a relationship OCB on the performance so that organizational effectiveness is achieved. The results of confirmatory factor analysis showed that the OCB primary reflected by the willingness to follow the development and progress made, to do something useful for others for the sake of progress organizations, attended the meeting, earnestly follow the rules, perform basic tasks, submit reports and work plans earlier than supposed and is willing to take the time to help others has been helping leaders to improve organizational performance by both

$\mathrm{H}_{7}$ : OCB employees can be improve organizational effectiveness

OCB has a positive and significant effect on organizational effectiveness with a p-value of 0.004 $>0.05$ and a coefficient standardized by 0.607 , this coefficient indicates that the better OCB, the higher organizational effectiveness (supported $\mathrm{H}_{7}$ ). The results of this study support the findings provide evidence that there is a positive relationship between OCB on organizational effectiveness (Foote \& Tang, 2008).

$\mathrm{H}_{8:} \quad$ Good leadership can be improve organizational effectiveness

Leadership has a positive and insignificant effect on organizational effectiveness with a p-value of $0.061>0.05$ and a coefficient standardized 0.199. This suggests that the role of a leader cannot directly increase the organizational effectiveness, but leadership indirect effect on organizational effectiveness through $\mathrm{OCB}$ and performance management (partially rejected $\mathrm{H}_{8}$ ). The role of a good leader will be able to create OCB at the organization's members and also at the same time improving performance management and will eventually create an organizational effectiveness. To be a good leader requires experience and understanding of the situational.

Intellectual stimulation is an indicator that has the highest average value of the variable leadership. This illustrates that the leader can bring new ideas, provide creative solutions to the problems faced by subordinates, and motivating subordinates to look for new approaches in carrying out organizational tasks. Aspects of intellectual stimulation positively correlated with extra effort, that is, leaders who can provide intellectual contributions continue to encourage staff to be able to devote effort to planning and problem solving (Seltzer \& Bass, 1990). The results of confirmatory factor analysis showed that the main indicators that make up the organization's effectiveness is further organizational characteristics of successive environmental characteristics, management characteristics and the characteristics of workers. The results showed that the effectiveness of the organization can be seen from the characteristics of the organization it is seen from the correspondence between competence with the task at hand and ease of communication between sectors.

$\mathrm{H}_{9:} \quad$ Employee competencies can be improve organizational effectiveness

Competence have a positive and insignificant effect on organizational effectiveness with a pvalue of $0.298>0.05$ and a coefficient standardized by 0.118 , this coefficient indicates that the 
competency of an individual can not directly increase the organizational effectiveness, but competence indirect effect on organizational effectiveness through OCB and performance management (partially rejected $\mathrm{H}_{9}$ ). This shows that the competence of a person will drive OCB at the organization's members and also simultaneously streamline performance management and will ultimately impact on organizational effectiveness.

This finding contrast with the results of research Apriani (2011), competence have significant effect on organizational effectiveness, better utilization of human resources that it will achieve the organization's objectives so that effectiveness can be achieved. The study also found that competency indirect effect on organizational effectiveness through OCB and performance management. Effectiveness of the ability of a person to choose the right destination or equipment for the achievement of the goals set. The effectiveness of employee is needed in an organization with the effectiveness of the employee, the purpose of an organization will be achieved in accordance with what is expected or achieved effectively and efficiently. Employees understand and recognize its part in contributing and in doing so, manage and improve the performance of both individuals and organizations. The results of confirmatory factor analysis explains that the competency of leadership is the ability to set an example so that the leadership can influence subordinates to behave for the good of the organization and encourage subordinates to behave OCB and created a management level of high performance.

\section{Conclusion and recommendations}

Good leadership is proven to improve OCB and performance management, leadership directly but cannot improve organizational effectiveness. The high of competence proven to improve OCB and performance management, competency directly but not able to improve organizational effectiveness. OCB is well proven to improve performance management and organizational effectiveness. The high level of performance management in practice proven to enhance organizational effectiveness. Implementation of organizational effectiveness demonstrated through their enthusiasm and efforts to improve services to interpret society as citizens who need quality services by providing service facilities are easy, safe, reliable employee, equitable, to give space for the public to file a complaint and responsive.

Improvements the fundamental need to be done so that the leadership and competence can be improved by increasing the quality of leadership and competence as the basis and terms of office suite, then implemented consistently mainly utilize optimally the assessment center. Creation OCB behaviors important to do especially on altruism and courtesy, for it can be done mapping and dissemination needs through training so that employees gain a better understanding so that the ability of employees working professionals in the execution of their duties and functions. Good governance as a civilian state apparatus which is an important factor in enhancing organizational effectiveness. For advanced researchers, the study was conducted in the public sector, so that it is possible to construct the same can also be done on the private sector to look at the consistency of the results.

\section{References}

Ahmad, S., Shahzad, K., Rehman, S., Khan, N. A., \& Shad, I. U. (2010). Impact of organizational commitment and organizational citizenship behavior on turnover intentions of call center personnel in Pakistan. European Journal of Social Sciences, 17(4), 585-591.

Apriani, F. (2011). Pengaruh Kompetensi, Motivasi, dan Kepemimpinan terhadap Efektivitas Kerja. Bisnis \& Birokrasi Journal, 16(1).

Armstrong, M., \& Baron, A. (2005). Managing performance: performance management in action. CIPD publishing. 
Bacal, Robert. (2001). Performance Management, Translator Surya Dharma \& Yanuar. Irawan. Jakarta: PT. Gramedia Pustaka Indonesia.

Baird, Lloyd. (1986). Managing Performance. John Wileyd Son, Inc. New York.

Bass, B. M. (1985). Leadership and performance beyond expectations. Free Press; Collier Macmillan.

Bass, B. M., Avolio, B. J., Jung, D. I., \& Berson, Y. (2003). Predicting unit performance by assessing transformational and transactional leadership. Journal of applied psychology, 88(2), 207.

Becker, Markus C. (2004). Organizational routines: a review of the literature. Industrial and corporate change 13 (4) 643-678.

Begum, N, (2005). The relationship between social power and organizational citizenship behavior: The meditational role of procedural justice, organizational commitment, and job satisfaction in context of a private commercial bank in Bangladesh. Unpublished doctoral dissertation, Independent University, Bangladesh.

Bums, J. M. (1978) Leadership. New York: Harper \& Row

Chang, R. (2011). Measuring Organizational Performance. Jakarta : PPM Manajemen

Dali, N., \& Mas'ud A., (2014) The Impact of Professionalism, Locus of Control, and Job Satisfaction on Auditors' Performance: Indonesian Evidence. International Journal of Business and Management Invention. Volume 3 (10) 63-73

Dessler, Gary. (2003). Human Resource Management Tenth Edition. New Jersey: Prentice Hall

Dirks, K.T. \& Ferrin, D. L. (2002) Trust in leadership: Meta-analytic finding and implication of research and practice. Journal of Applied Psychology, 71 (3), 500-507.

Foote, D. A., \& Li-Ping Tang, T. (2008). Job satisfaction and organizational citizenship behavior (OCB) Does team commitment make a difference in self-directed teams?. Management Decision, 46(6), 933-947.

Gibson, Ivancevich, \& Donnelly. (1996). Organization, Behavior, Structure, Processes. Bina. Rupa Aksara. Jakarta.

Gunadi, (2007). Tax Accounting, Third Edition, First Edition, Jakarta. PT. Gramedia Wydia Sarana Indonesia,

Hair, J., Black, W., Babin, B., Anderson, R., \& Tatham, R. (2006). Multivariate data analysis (6th ed.). Uppersaddle River, N.J.: Pearson Prentice Hall.

Hofstede, G. H. (2001). Culture's consequences: Comparing values, behaviors, institutions and organizations across nations. Sage.

House, R. J. (1995). Leadership in the 21st century: A speculative enquiry. In: Howard, A. (Ed.), The changing nature of work. San Francisco: Jossey Bass

Katz, D., \& Kahn, R. L. (1978) The social psychology of organizations. New York: Wiley, 2nd ed.

Konovsky, M. A., \& Pugh, S. D. (1994). Citizenship behavior and social exchange. Academy of management journal, 37(3), 656-669.

Kotter, J.P. (1996), Leading Change, Pioneering Change, (Joseph. Bambang MS, Translator) Jakarta: PT Gramedia Pustaka Utama

Mahmudi. (2005). Public Sector Performance Management. Yogyakarta: UPP AMP YKPN

Mangkunegara.Anwar Prabu. (2005). Human Resources in company. Remaja. Rosdakarya: Bandung.

Mitrani, A., Dalziel, M., \& Fitt, D. (1992). Competency Based Human Resource Management. HayGroup.

Moenir. (2006). Management of Public Services in Indonesia. Jakarta: PT. Bumi Aksara.

Organ, D. W. (1988). Organizational citizenship behavior: The good soldier syndrome. Lexington Books/DC Heath and Com.

Organ, D. W. (1990). The motivational basis of organizational citizenship behavior. Research in organizational behavior, 12(1), 43-72. 
Palan, R. (2007). Competency Management. Jakarta: Publisher PPM

Patnaik, S., \& Biswas, S. (2005). The Mediating Role of Organizational Citizenship Behavior between Organizational Identification and Its Consequences. Online Submission.

Podsakoff, P. M., Ahearne, M., \& MacKenzie, S. B. (1997). Organizational citizenship behavior and the quantity and quality of work group performance. Journal of applied psychology, 82(2), 262.

Rivai Veithzal, (2008). Human Resource Management For Corporations: Theory and Practice, PT. RajaGrafindo Persada, Jakarta.

Schleicher, D. J., Watt, J. D., \& Greguras, G. J. (2004). Reexamining the job satisfactionperformance relationship: the complexity of attitudes. Journal of applied psychology, $89(1), 165$.

Seltzer, J., \& Bass, B. M. (1990). Transformational leadership: Beyond initiation and consideration. Journal of management, 16(4), 693-703.

Semin, G. R., \& Fiedler, K. (1996). Applied Social Psychology. London : Sage Publications

Sloat, K. C. (1999). Organizational citizenship. Professional safety, 44(4), 20.

Smith, C. A., Organ, D. W., \& Near, J. P. (1983). Organizational citizenship behavior: Its nature and antecedents. Journal of applied psychology, 68(4), 653.

Spencer, L. M., \& Spencer, P. S. M. (2008). Competence at Work models for superior performance. John Wiley \& Sons.

Steers, M. Richard. (1985). Organizational Effectiveness. Jakarta: Erlangga

Sudarma, K. (2012). Welfare analysis of performance based on competency and organizational citizenship behavior (OCB) on labour administration Case Studies at the State University of Semarang (UNNES). Socio-Economic Dynamic

Sudarwan, Danim. (2004). Motivation and Leadership Effectiveness Group. Bengkulu: PT Rineka Cipta.

Tintin, S. (2015). Influence of Leadership Style on employee performance at the SBU Postal Operations Directorate Prima PT Pos Indonesia (Persero). Journal of Management, 9 (2).

Titisari, K. H., \& Alviana, K. (2012). Influence on Economic Performance Environmental Performance. Journal of Accounting and Finance Indonesia, 9 (1), 56-67.

Walumbwa, F. O., Avolio, B. J., \& Zhu, W. (2008). How transformational leadership weaves its influence on individual job performance: The role of identification and efficacy beliefs. Personnel Psychology, 61(4), 793-825.

Wibowo. (2007). Performance Management. Jakarta. PT. Raja Grafindo Parsada

Williams, R. S. (1998). Performance management: Perspectives on employee performance. International Thomson Business Press.

Yudhaningsih, Resi. (2011). Improving the Effectiveness of Work Through Commitment, and Organizational Culture Change, Journal of Development, Humanities, Vol.11 No. 1

Zheng, W., Yang, B., \& McLean, G. N. (2010). Linking organizational culture, structure, strategy, and organizational effectiveness: Mediating role of knowledge management. Journal of Business research, 63(7), 763-771. 